\title{
Cross-linked growth hormone dimers have enhanced biological activity
}

\author{
James W Mockridge, Roger Aston ${ }^{1}$, David J Morrell ${ }^{2}$ and Andrew T Holder \\ The Babraham Institute, Babraham, Cambridge CB2 4AT, UK, ${ }^{1}$ Peptec (UK Ltd), 60 Dyer Street, Cirencester GL7 2 PF, UK and ${ }^{2}$ Reproductive \\ Medicine Laboratory, University of Edinburgh, Centre for Reproductive Biology, 37 Chalmers Street, Edinburgh EH9 3EW, UK \\ (Correspondence should be addressed to J W Mockridge, Department of Cardiology, The Rayne Institute, St Thomas's Hospital, Lambeth Palace Road, \\ London SE1 7EH, UK)
}

\begin{abstract}
In this study we have investigated the effect on the bioactivity of pituitary-derived human growth hormone (hGH) and recombinant bovine (b) GH after the addition of various concentrations of the water soluble cross-linking agent 1-ethyl-3(3-dimethylaminopropyl) carbodiimide (EDC; 6.25$100 \mathrm{mg} / \mathrm{ml}$ ). The biological activity of resulting cross-linked reactions were determined by its ability to promote incorporation of ${ }^{35} \mathrm{SO}_{4}{ }^{2-}$ into costal cartilage of hypopituitary Snell dwarf mice in vivo. Administration of EDC-treated hGH solutions resulted in a significant enhancement of hormone activity in vivo compared with non-cross-linked samples. A similar significant enhancement of bGH activity in vivo was also observed when solutions containing recombinant bGH were cross-linked using EDC. For both hGH and bGH the degree of enhancement appears to be dose-dependent for the concentration of EDC $(6.25-100 \mathrm{mg} / \mathrm{ml}$ for $\mathrm{hGH} ; 6.25-50 \mathrm{mg} / \mathrm{ml}$ for bGH) present in the crosslinking reactions. SDS-PAGE analysis of EDC cross-linked solutions containing hGH and bGH spiked with ${ }^{125} \mathrm{I}-\mathrm{hGH}$ and ${ }^{125} \mathrm{I}-\mathrm{bGH}$ respectively revealed that dimeric $\mathrm{GH}$ was the primary cross-linked component. Increasing the concentration of EDC in cross-linking reactions resulted in increased formation of dimeric hGH and bGH. There was a significant correlation between the amount of GH dimer present and the increase in biological activity, suggesting that GH dimers were responsible for the enhanced biological activity. This was confirmed by the enhanced biological activity of a purified preparation of EDC cross-linked dimeric hGH.

In conclusion, covalently cross-linked GH dimers reported here have enhanced bioactivity in vivo. However, since naturally occurring GH dimers are known to have reduced biological activity, this work suggests that the structure of EDC cross-linked GH dimers differs fundamentally from that of native dimeric hGH.
\end{abstract}

European Journal of Endocrinology 138 449-459

\section{Introduction}

Pituitary growth hormone $(\mathrm{GH})$ is a multifunctional polypeptide hormone that exhibits somatogenic, lactogenic and diabetogenic activity (1). The structures of both porcine $\mathrm{GH}(\mathrm{pGH})$ and human $\mathrm{GH}(\mathrm{hGH})$ have been determined by high resolution X-ray crystallographic studies; they are $4 \alpha$-helix bundle proteins with connections between the helixes formed by varying lengths of loop/coil structure $(2,3)$. This structural arrangement is thought to be shared by the GH-related proteins prolactin and placental lactogen and by other members of the larger family of haematopoietins (4-6). $\mathrm{GH}$ receptors are also structurally related to receptors for other haematopoietins; this structural homology is most apparent in the extracellular domain of these single transmembrane proteins (7). Other emerging features of this receptor family are ligand-induced receptor dimerisation which has been observed for both GH (3) and prolactin (8), and tyrosine phosphorylation and activation of the JAK family of receptorassociated tyrosines $(8-11)$ and members of the STAT family of transcription factors $(12-14)$.

Growth hormone is polymorphic comprising the predominant $22 \mathrm{kDa}$ form, a $20 \mathrm{kDa}$ variant, which lacks residues $32-46$ (15), and $45 \mathrm{kDa}$ dimeric $\mathrm{GH}$ (16-19); there are also a large number of less well characterised variants $(20,21)$. Dimeric GH is thought to represent about $10-20 \%$ of GH in pituitary extracts. About $70 \%$ of naturally occurring dimers are noncovalently linked; of the $30 \%$ which are covalently linked the majority are joined via inappropriate intermolecular disulphide bridges $(18,21)$. For example, Lewis et al. (18) reported a disulphide dimer where cys 35 and cys ${ }^{182}$ in one molecule are linked to cys ${ }^{165}$ and cys $^{189}$ respectively in a second GH molecule. The somatogenic activity of such dimers, whether covalently linked or otherwise, appears to be around $10 \%$ of that 
observed for monomeric $22 \mathrm{kDa} \mathrm{GH}(18,22)$. Little is known of the three-dimensional structure of dimeric $\mathrm{GH}$ and how it may differ from that proposed for monomeric $\mathrm{GH}$.

In a previous study we attempted to examine the biological activity of bovine $\mathrm{GH}(\mathrm{bGH})$ when cross-linked to BSA. The cross-linking process, which utilised carbodiimide, resulted in a significant increase in the ability of bGH to promote cartilage metabolism in hypopituitary Snell dwarf mice in vivo. However, the preliminary data also suggested that it was cross-linked $\mathrm{GH}$ dimers rather than GH/BSA complexes which were responsible for the enhanced activity (23). This paper reports an examination of this phenomenon and demonstrates that chemically cross-linked GH dimers have enhanced biological activity.

\section{Materials and methods}

\section{Materials}

Outdated MRC clinical grade pituitary GH was rechromatographed on Sephadex G-100 followed by Sephadex G-50 (Pharmacia LKB Biotech., St Albans, Herts, UK) and the monomer peak was retained and freeze-dried. SDS-PAGE analysis of this peak revealed a single band at $22 \mathrm{kDa}$. Recombinant bGH was obtained from the Monsanto Corporation (St Louis, MO, USA). The crosslinking agent 1-ethyl-3-(3-dimethylaminopropyl) carbodiimide hydrochloride (EDC) was obtained from Pierce Chemicals, Life Science Laboratories Ltd (Luton, Beds, UK). All chemicals and molecular weight (MW) markers used in polyacrylamide gel electrophoresis were obtained from Sigma (Poole, Dorset, UK); radiochemicals $\left({ }^{125} \mathrm{I}\right.$ and $\left.{ }^{35} \mathrm{SO}_{4}{ }^{2-}\right)$ were obtained from Amersham International plc (Amersham, Bucks, UK). All other reagents were purchased from BDH (Poole, Dorset, UK).

\section{Iodination of hGH}

Monomeric hGH, prepared as above, and recombinant bGH were iodinated to a specific activity of $50-60 \mu \mathrm{Ci} /$ $\mu \mathrm{g}$ using Iodogen (1,3,4,6-tetrachloro-3 $\alpha, 6 \alpha$-diphenyl glycoluril; Pierce Chemicals) by the method of Fraker and Speck (24). Iodinated hormone was separated from free iodine by column chromatography on a PD10 column (Pharmacia LKB Biotech).

\section{Cross-linking reaction and purification of $G H$ dimer}

In all cross-linking reactions equal volumes of $\mathrm{GH}$ and $\mathrm{EDC}$ were mixed such that the final concentration of $\mathrm{GH}$ was $1 \mathrm{mg} / \mathrm{ml}$. EDC, which was added last, was dissolved in PBS, diluted appropriately (final concentration 0$100 \mathrm{mg} / \mathrm{ml}$ ) and added immediately. Non-cross-linked control solutions were treated identically except that buffer was substituted for EDC. Samples $(100 \mu \mathrm{l})$ for PAGE analysis were taken from EDC reaction mixtures immediately after the addition of EDC and added to tubes containing $5 \mu \mathrm{l}{ }^{125} \mathrm{I}-\mathrm{hGH}$ (370 000 c.p.m.). All cross-linking reactions were incubated for $2 \mathrm{~h}$ at room temperature. Solutions used to treat mice were dialysed extensively against PBS and diluted to give the stated concentration of $\mathrm{GH}$ in an injection volume of $100 \mu \mathrm{l}$.

Where hGH was cross-linked in order to purify GH dimers, $200 \mathrm{mg}$ EDC were dissolved in $1 \mathrm{ml}$ PBS and added to $15 \mathrm{mg} \mathrm{hGH}$ in $3 \mathrm{ml}$ PBS and incubated for $2 \mathrm{~h}$ at room temperature. Column chromatography on a $50 \times 3.5 \mathrm{~cm}$ Sephadex G-50 column, equilibrated with PBS, was used to separate monomeric and dimeric hGH. An initial column run gave a partially pure preparation of dimer; this peak was re-run on Sephadex G-50 and the dimer peak gave a single band on PAGE (see Fig. 5). After each Sephadex G-50 run the dimer peak was concentrated using a Vivapore concentrator (Viva Science, Lincoln, Lincs, UK). Doses of purified dimer or monomer hGH used in the dwarf mouse assay were calculated from protein estimations using Coomassie Protein Assay Reagent (Pierce Chemicals) according to the manufacturer's instructions.

\section{SDS-PAGE}

SDS-PAGE was performed according to the method of Laemmli (25) on a Bio-Rad vertical slab gel unit with $1.5 \mathrm{~mm}$ thick gels. Samples of the cross-linking reactions were mixed with an equal volume of buffer containing SDS $(4 \% \mathrm{w} / \mathrm{v})$, glycerol $(20 \% \mathrm{v} / \mathrm{v})$, bromophenol blue $(0.5 \% \mathrm{w} / \mathrm{v})$ and mercaptoethanol $(4 \% \mathrm{v} / \mathrm{v})$ and heated at $100{ }^{\circ} \mathrm{C}$ for $2 \mathrm{~min}$ prior to loading. Samples $(20 \mu \mathrm{l})$ were applied to a $5-15 \%$ gradient gel with a $3 \%$ stacking gel and run at $30 \mathrm{~mA} /$ gel. Gels were stained with $0.1 \%$ Kenacid blue in $10 \%$ acetic acid $(\mathrm{w} / \mathrm{v})$ and $20 \%$ methanol (v/v) and destained using $7 \%$ acetic acid and $20 \%$ methanol. Bands in each lane were mapped by comparison with MW standards obtained from Sigma. Each lane was cut into $60 \times 2 \mathrm{~mm}$ slices and the ${ }^{125} \mathrm{I}-\mathrm{hGH}$ present in each section was determined by counting on a Packard Cobra gamma counter.

\section{Animal experiments}

The bioactivities of the various cross-linked preparations of $\mathrm{GH}$ and the equivalent non-cross-linked controls were assessed by their effects on cartilage metabolism in hypopituitary Snell dwarf mice. Small size in these animals (30\% of normal) is a consequence of defective differentiation of the anterior pituitary gland (26) which secretes negligible amounts of $\mathrm{GH}$, prolactin and thyrotrophin; these primary defects result in low circulating levels of the thyroid hormones and insulin-like growth factor-I (27-30). Dwarf mice (aged 9-11 weeks and weighing $8-11 \mathrm{~g}$ at the start of the experiment) were bred, maintained, marked and caged as described previously (31). No differences have been detected between the responses of male and female mice to $\mathrm{GH}$ 
treatment and they were therefore pooled and used at random. Mice were injected $(0.1 \mathrm{ml})$ subcutaneously in the back of the neck once per day for two days with $\mathrm{GH}$ either cross-linked or non-cross-linked $(n=6 /$ treatment group). They received ${ }^{35} \mathrm{SO}_{4}{ }^{2-}$ on the third day $(0.5 \mu \mathrm{Ci} /$ g body weight, i.p.) and were killed $20 \mathrm{~h}$ later. Rib cages were removed, costal cartilages were dissected out, pooled for each animal, dried, weighed, solubilised in $200 \mu \mathrm{l}$ 98\% formic acid, mixed with $3.5 \mathrm{ml}$ scintillation fluid and counted on a Packard TriCarb 2500TR liquid scintillation counter as described previously (31). Results were expressed as d.p.m./mg cartilage. All procedures and care of animals were carried out in accordance with Home Office (UK) regulations.

\section{Statistics}

All values are expressed as means \pm s.E.M. $(n=6)$. Differences between groups were assessed using twotailed Student's t-test. Correlation coefficients, slopes and significances of slopes were calculated using standard statistical procedures. For investigation of dose dependency these statistical procedures were carried out after log transformation of EDC doses (expressed as d.p.m./log dose unit).

\section{Results}

In the initial investigation, groups of mice were treated with cross-linked complexes produced in reactions containing pituitary-derived hGH plus increasing concentrations of EDC $(6.25-200 \mathrm{mg} / \mathrm{ml})$. The effects of the various cross-linked complexes on cartilage metabolism in hypopituitary Snell dwarf mice are illustrated in Fig. 1. Uptake of ${ }^{35} \mathrm{SO}_{4}{ }^{2-}$ was significantly enhanced $(P<0.01)$ by hGH after the addition of EDC concentrations of $25 \mathrm{mg} / \mathrm{ml}$ and above with a maximum enhancement being obtained with hGH cross-linked with $100 \mathrm{mg} / \mathrm{ml}$ EDC. The response of hGH plus 6.25$100 \mathrm{mg} / \mathrm{ml}$ EDC appeared to be dose-dependent for the concentration of EDC (b (regression coefficient $)=1459$ d.p.m. $/ \log$ dose unit; $P<0.001)$. The response of animals receiving complexes formed in reactions containing hGH plus $200 \mathrm{mg} / \mathrm{ml}$ EDC declined; however, in this case a precipitate was observed after the cross-linking reaction. Non-crosslinked hGH promoted a significant increase in cartilage metabolism compared with animals receiving PBS $(P<0.001)$.

SDS-PAGE was used to determine the molecular weights of the various complexes produced in crosslinking reactions (Fig. 2) the biological activities of which are illustrated in Fig. 1. The size distribution of ${ }^{125} \mathrm{I}-\mathrm{hGH}$ in samples obtained from cross-linking reactions containing $\mathrm{GH}$ and $0,6.25,12.5$ or $25 \mathrm{mg} / \mathrm{ml} \mathrm{EDC}$ are illustrated in Fig. 2a and hGH and 0, 50 and 100 EDC in Fig. 2b. Molecular weight determinations were carried out on a 5-15\% gradient gel by comparison with commercially available MW standards. It is evident from Fig. 2a and $b$ that the vast majority of $\mathrm{GH}$ (over
Figure 1 The effect of cross-linked complexes produced in reactions containing hGH plus increasing concentrations of EDC $(0-200 \mathrm{mg} /$ $\mathrm{ml}$ ) on ${ }^{35} \mathrm{SO}_{4}{ }^{2-}$ uptake into costal cartilage of hypopituitary Snell dwarf mice in vivo. All cross-linked and non-cross-linked reaction solutions were diluted to give a final concentration of $40 \mu \mathrm{g} \mathrm{hGH} / 0.1 \mathrm{ml}$ (injection volume); control groups injected with PBS containing $50 \mathrm{mg} / \mathrm{ml} \mathrm{EDC}$ and PBS alone were also included. Values are means \pm S.E.M.; $n=6$ per group. Mice received one injection/day for two days. ${ }^{\star \star} P<0.01,{ }^{\star \star \star} P<0.001$ compared with the group receiving non-cross-linked hGH.

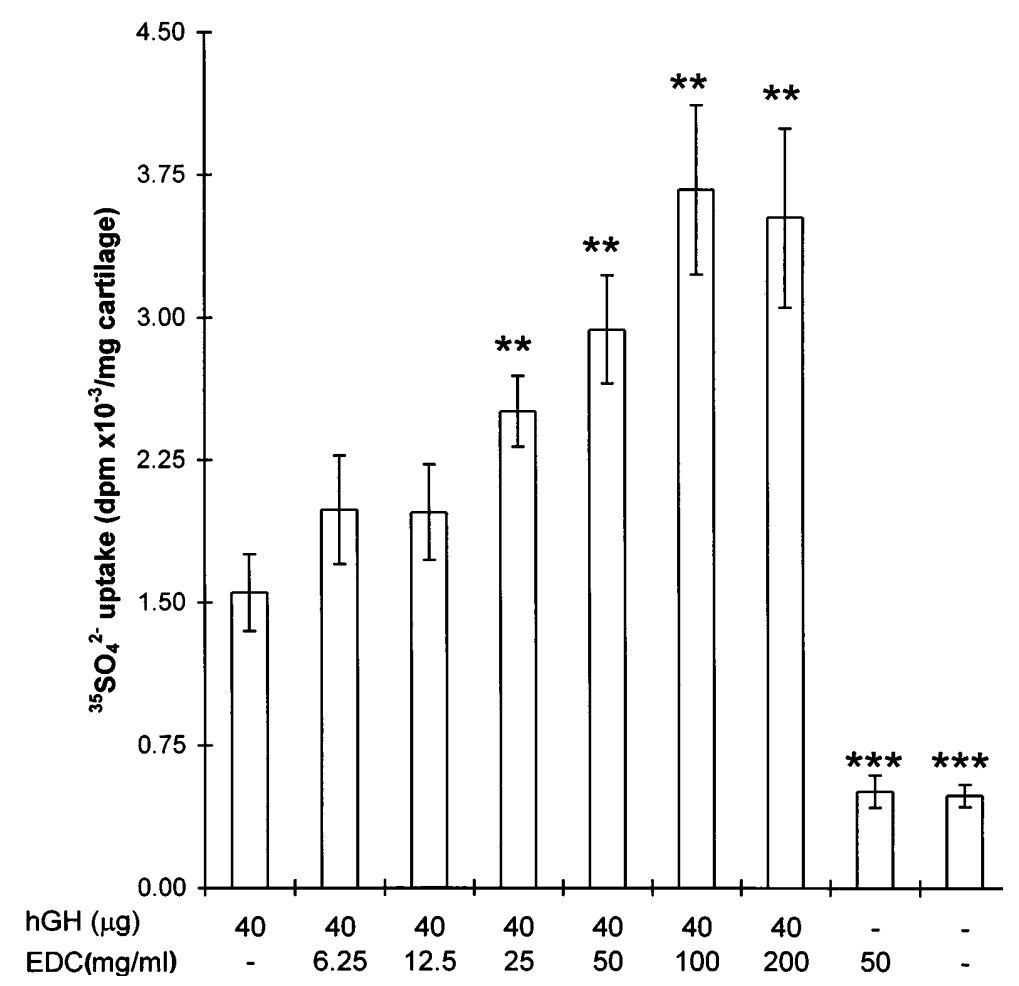


a

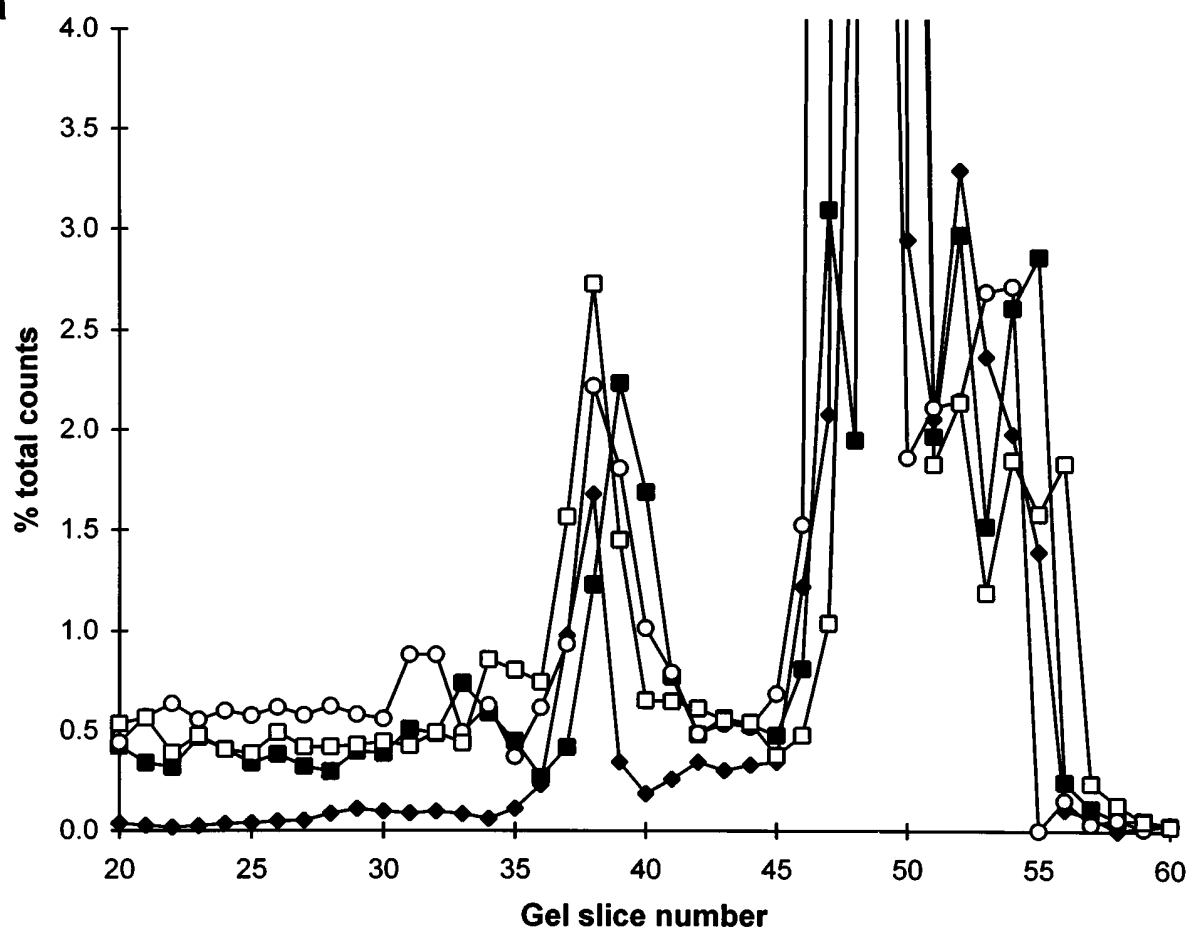

b

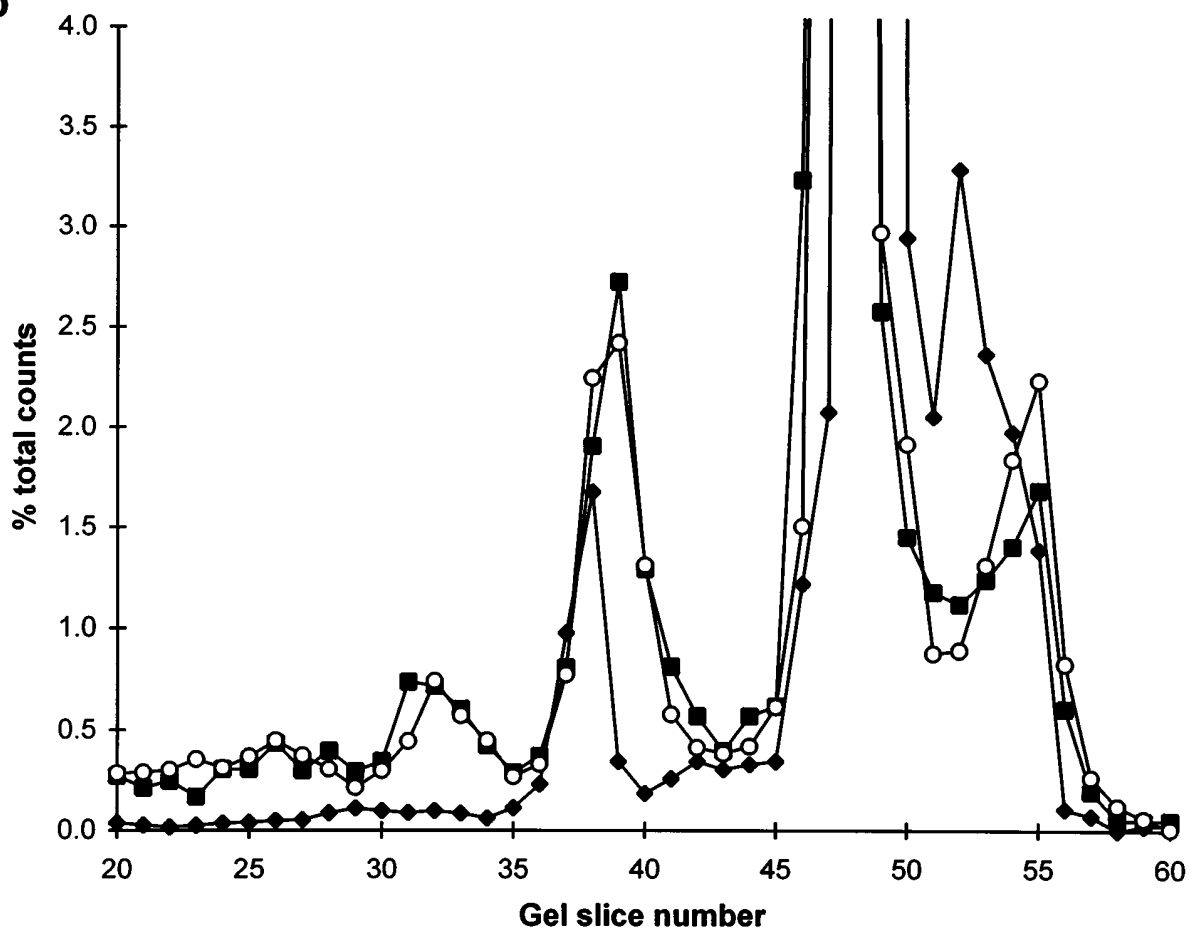

Figure 2 PAGE analysis of EDC cross-linked reactions containing hGH spiked with ${ }^{125} \mathrm{I}$-hGH. Each lane was cut into 2-mm sections and counted on a gamma counter. The MWs of the 'peaks' of ${ }^{125} \mathrm{I}-\mathrm{hGH}$ containing complexes were assessed by comparison with MW standards run on the same gel. (a) PAGE analysis of hGH non-cross-linked ( ), hGH plus $6.25 \mathrm{mg} / \mathrm{ml}$ EDC (ם), hGH plus $12.5 \mathrm{mg} / \mathrm{ml} \mathrm{EDC} \mathrm{(O)} \mathrm{and} \mathrm{hGH} \mathrm{plus}$ $25 \mathrm{mg} / \mathrm{ml}$ EDC ( $\square$ ). (b) PAGE analysis of hGH alone non-cross-linked ( $\bullet$ ), hGH plus $50 \mathrm{mg} / \mathrm{ml} \mathrm{EDC} \mathrm{( \square )} \mathrm{and}$ hGH plus $100 \mathrm{mg} / \mathrm{ml}$ EDC (O). Dimeric hGH was found in gel slices 38-43 and monomeric hGH in gel slices 
90\%) remains uncross-linked and has a relative mobility $\left(R_{\mathrm{f}}\right)$ appropriate to monomeric hGH. Also, non-cross-linked control contained a small but significant amount $(3.4 \%)$ of $\mathrm{GH}$ dimer $(44 \mathrm{kDa})$ which was not converted to monomer by the presence of mercaptoethanol. This dimer was presumably formed either during freeze drying or storage (at $-30^{\circ} \mathrm{C}$ ) of our 'monomeric' hGH preparation, or is a product of the iodination process. This dimer has been isolated and has reduced bioactivity compared with monomeric GH (results not shown). The presence of increasing concentrations of EDC in reaction mixtures containing hGH was associated with increasing amounts of ${ }^{125} \mathrm{I}$-hGH appearing in the GH dimer region. For all samples the GH dimer peak was found in gel slices 38-43. Counts in these sections (minus background) were summed and expressed as a percentage of counts loaded onto the gel in order to calculate the percentage cross-linking of ${ }^{125} \mathrm{I}$-hGH in each cross-linking reaction; these values are given in Table 1 . Relatively little ${ }^{125} \mathrm{I}-\mathrm{hGH}$ was found at MWs higher than $44 \mathrm{kDa}$. A highly significant correlation between increased biological activity and the percentage EDC cross-linked hGH dimer present in each daily injection was observed $(r=0.95 ; P<0.001)$. Similar observations have been obtained from three separate experiments with similar patterns being observed in each.

In order to determine whether this enhancing phenomenon is peculiar to hGH or simply the preparation used, cross-linking reactions using recombinant bGH were investigated. For bGH, the cross-linking reactions were repeated with EDC concentrations between $0-100 \mathrm{mg} / \mathrm{ml}$ and ${ }^{125} \mathrm{I}-\mathrm{bGH}$ as tracer instead of ${ }^{125} \mathrm{I}-\mathrm{hGH}$. The addition of EDC at concentrations of 12.5$50 \mathrm{mg} / \mathrm{ml}$ to the samples stimulated significant increases in ${ }^{35} \mathrm{SO}_{4}{ }^{2-}$ uptake compared with bGH alone, with a maximum enhancement being produced by bGH plus $50 \mathrm{mg} / \mathrm{ml} \mathrm{EDC} \mathrm{(Fig.} \mathrm{3).} \mathrm{As} \mathrm{for} \mathrm{hGH,} \mathrm{the} \mathrm{response} \mathrm{(bGH} \mathrm{plus}$ $6.25-50 \mathrm{mg} / \mathrm{ml} \mathrm{EDC}$ ) appeared to be dose-dependent for the concentration of EDC ( $b=1406$ d.p.m./log dose unit; $P<0.01)$. However, bGH cross-linked with $100 \mathrm{mg} / \mathrm{ml}$ EDC produced a decrease in ${ }^{35} \mathrm{SO}_{4}{ }^{2-}$ uptake compared with bGH plus $50 \mathrm{mg} / \mathrm{ml}$; in this case a precipitate was observed after the cross-linking reaction. Non-crosslinked bGH control groups promoted a significant increase in cartilage metabolism compared with animals receiving PBS $(P<0.001)$.

Examination of the size distribution of ${ }^{125} \mathrm{I}$-bGH in samples obtained from the subsample cross-linking reactions showed they were similar to those described for hGH and are illustrated in Fig. $4 a$ and b. For all the samples the bGH dimer peak was found in gel slices $28-$ 34 with the monomeric peak found in gel slices $42-47$. The majority of bGH remained in the non-cross-linked monomeric form. In this preparation of bGH a small proportion (approx. 1\%) of 'naturally occurring' dimer was found in the non-cross-linked sample but this was considerably less than in the pituitary-derived hGH preparation (Table 2). As for hGH, addition of increasing concentrations of EDC in the reaction mixtures was associated with increasing amounts of ${ }^{125} \mathrm{I}-\mathrm{bGH}$ appearing in the dimer region; a highly significant correlation was observed between the increased biological activity induced by cross-linking and the percentage EDC crosslinked bGH ( $r=0.97$; $P<0.001)$. Similar observations have been obtained from three separate experiments with similar patterns being observed in each. Treatment of Snell dwarf mice with EDC-treated solutions of ovine $\mathrm{GH}$ and pGH also resulted in a significant increase in ${ }^{35} \mathrm{SO}_{4}{ }^{2-}$ incorporation compared with non-cross-linked samples (results not shown).

The enhanced biological activity of the 'unpurified' cross-linked complexes in all the species of GH studied appeared to be due to an increase in the amount of dimeric GH formed rather than to the source (pituitary or recombinant) of the material used. Therefore, in order to investigate whether covalently cross-linked $\mathrm{GH}$ dimers themselves have enhanced biological activity,

Table 1 The effect of various concentrations of the cross-linking agent EDC on the biological activity of hGH and the formation of cross-linked hGH dimers. (A) The uptake of ${ }^{35} \mathrm{SO}_{4}{ }^{2-}$ into costal cartilage of Snell dwarf mice (d.p.m./mg cartilage) promoted by GH crosslinked by various concentrations of EDC $(0-100 \mathrm{mg} / \mathrm{ml})$. (B) The increase in ${ }^{35} \mathrm{SO}_{4}{ }^{2-}$ attributable to the cross-linking process (values for non-cross-linked hGH alone were subtracted from the appropriate EDC cross-linked values). (C) Dimeric hGH present in each reaction as calculated from gel slices from Fig. 2a and b. (D) The percentage of EDC GH dimer attributable to cross-linking with EDC (percentage of hGH dimer in EDC cross-linked reactions minus that in non-cross-linked hGH alone reaction).

\begin{tabular}{|c|c|c|c|c|c|c|c|c|}
\hline hGH $(40 \mu \mathrm{g} /$ day $)$ & + & + & + & + & + & + & - & - \\
\hline $\begin{array}{l}\text { EDC }(\mathrm{mg} / \mathrm{ml}) \text { present in } \\
\text { cross-linking reactions }\end{array}$ & - & 6.25 & 12.5 & 25 & 50 & 100 & 50 & - \\
\hline $\begin{array}{l}\text { (A) }{ }^{35} \mathrm{SO}_{4}{ }^{2-} \text { uptake (dpm) } \\
\text { (plotted values Fig. 1) }\end{array}$ & 1552 & 1987 & 1973 & 2505 & 2935 & 3670 & 510 & 491 \\
\hline $\begin{array}{l}\text { (B) Increased }{ }^{35} \mathrm{SO}_{4}{ }^{2-} \\
\text { uptake due to cross- } \\
\text { linking }\end{array}$ & - & 435 & 421 & 953 & 1383 & 2118 & - & - \\
\hline (C) \% dimer (total) & 3.40 & 6.81 & 7.36 & 8.07 & 8.10 & 8.19 & - & - \\
\hline (D) $\%$ EDC dimer & 0 & 3.41 & 3.96 & 4.67 & 4.70 & 4.79 & - & - \\
\hline
\end{tabular}




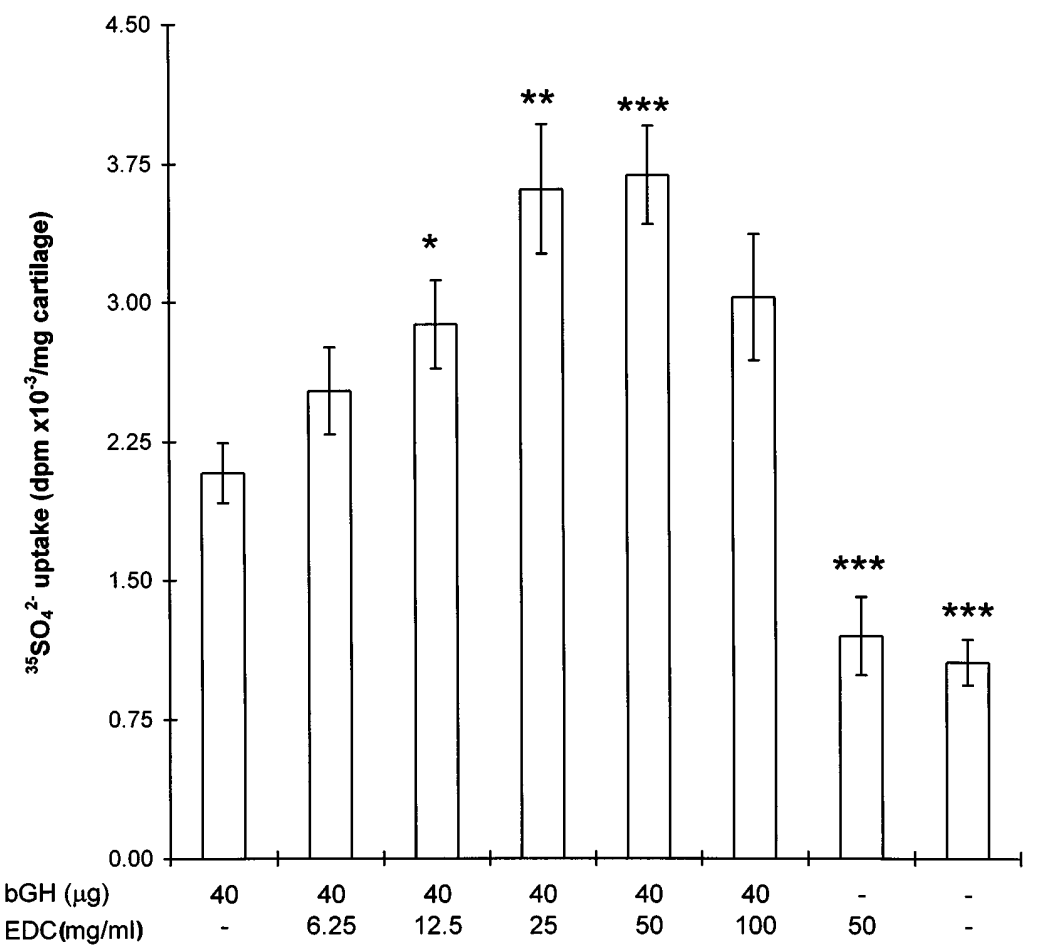

Figure 3 The effect of cross-linked complexes produced in reactions containing bGH plus increasing concentrations of EDC $(0-100 \mathrm{mg} /$ $\mathrm{ml}$ ) on ${ }^{35} \mathrm{SO}_{4}^{2-}$ uptake into costal cartilage of hypopituitary Snell dwarf mice in vivo. All cross-linked and non-cross-linked reaction solutions were diluted to give a final concentration of $40 \mu \mathrm{g} \mathrm{bGH} / 0.1 \mathrm{ml}$ (injection volume); control groups injected with PBS containing $50 \mathrm{mg} / \mathrm{ml} \mathrm{EDC}$ and PBS alone were also included. Values are means \pm S.E.M.; $n=6$ per group. Mice received one injection/day for two days. ${ }^{*} P<0.05,{ }^{* *} P<0.01,{ }^{* * *} P<0.001$ compared with the group receiving non-crosslinked bGH.
hGH was cross-linked to itself using EDC and the resulting covalently linked $\mathrm{GH}$ dimers purified and assayed for biological activity. Cross-linking reactions were carried out using $50 \mathrm{mg} / \mathrm{ml}$ EDC and the degree of cross-linking (about 10\%) was established as described above. Purification of cross-linked dimeric GH was achieved by column chromatography on Sephadex G-50. SDS-PAGE analysis of the hGH monomer and hGH dimer peaks after the first Sephadex G-50 run showed that the monomer peak was contaminated by dimer and vice versa. In addition, the dimer peak also had a small band of what appeared to be GH trimer. The hGH dimer peak from the first Sephadex G-50 run was then rechromatographed on Sephadex G-50. SDS-PAGE analysis of the resulting monomer and dimer peaks showed complete separation of monomeric and dimeric hGH (Fig. 5); however, a small amount of what may be trimeric hGH was still present. It is interesting to note that a significant amount of the dimer present in our inhouse preparation of naturally occurring dimer (also run on the gel) is not converted to monomeric hGH by SDS-PAGE under reducing conditions.

The biological activity of purified cross-linked hGH dimers was compared with that of purified EDC-exposed monomeric GH in the hypopituitary Snell dwarf mice model (Fig. 6). Monomeric hGH (5, 20 and $80 \mu \mathrm{g} /$ day) promoted a significant dose-dependent increase in cartilage metabolism $(b=988$ d.p.m./log dose unit; $P<0.001)$. The response to $5 \mu \mathrm{g}$ dimeric $\mathrm{GH}$ did not differ significantly from that observed with the same dose of monomeric $\mathrm{GH}$; this is probably due to the concentra- tion being the lowest point on the dose-response curve. However, the response to $20 \mu \mathrm{g}$ cross-linked dimer was significantly greater than that observed for the same dose of monomeric $\mathrm{GH}(P<0.001)$. All groups which received $\mathrm{GH}$ (monomer or dimer) promoted a significantly greater increase in cartilage metabolism than the PBS-injected group $(P<0.001$ in all cases). No difference in biological activity was observed when EDC-exposed monomer was compared with our monomer preparation of hGH (results not shown).

\section{Discussion}

From the data presented here it is clear that the crosslinking agent EDC can be used to enhance the biological activity of either hGH or bGH (Figs 1 and 3) irrespective of the origin (pituitary or recombinant) of the hormone. Furthermore, the degree of enhancement appears to be dose-dependent for the concentration of EDC present in the cross-linking reaction. PAGE analysis of crosslinking reactions which contained hGH (Fig. 2) and bGH (Fig. 4) revealed a significant correlation between the amount of EDC cross-linked dimeric $\mathrm{GH}$ and biological activity (Table 1 for hGH and Table 2 for bGH). This suggests that GH dimers are the active component. The enhanced biological activity of purified EDC cross-linked hGH dimers (Fig. 6) clearly supports this view.

In contrast to the dimers reported here native $\mathrm{GH}$ dimers have a reduced bioactivity compared with monomeric $\mathrm{GH}(18,20,21)$ and thus it appears that 
$\mathbf{a}$

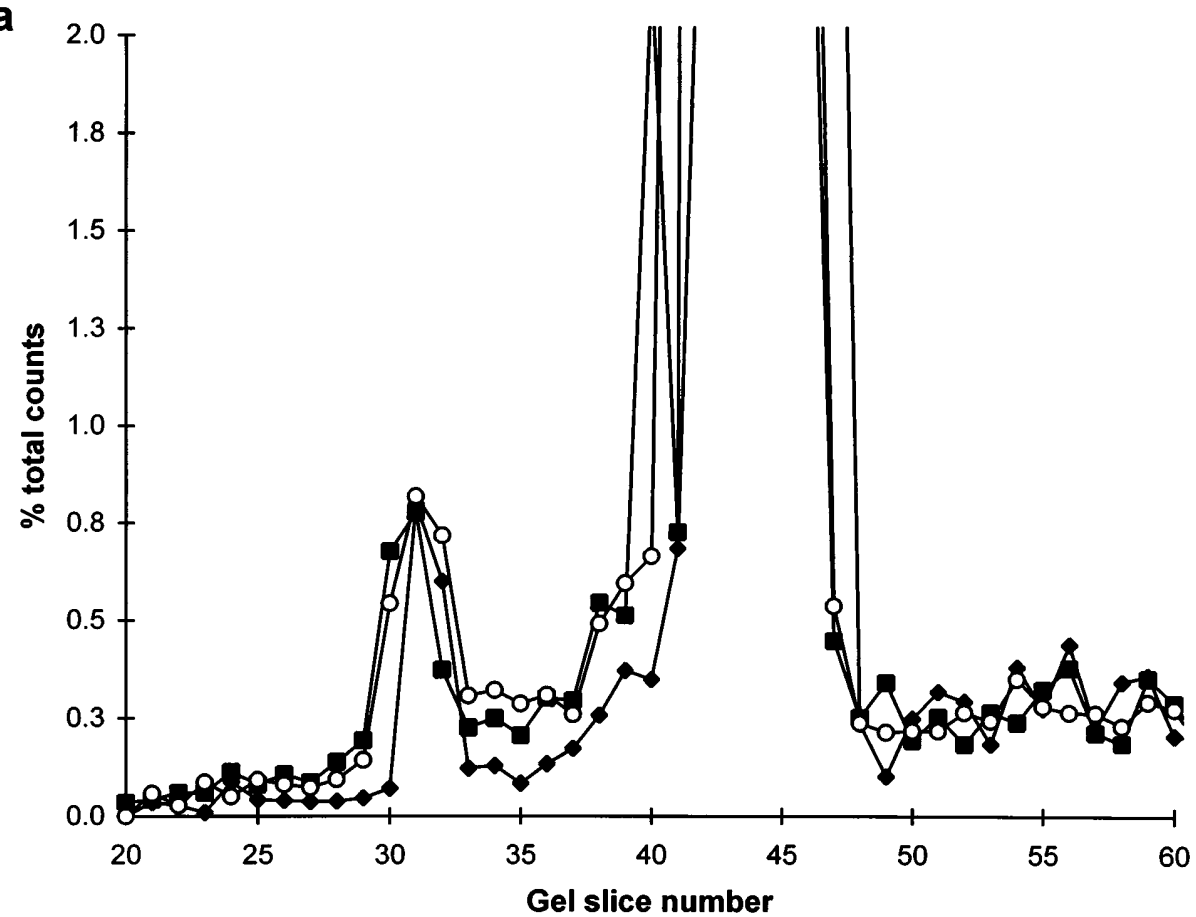

b

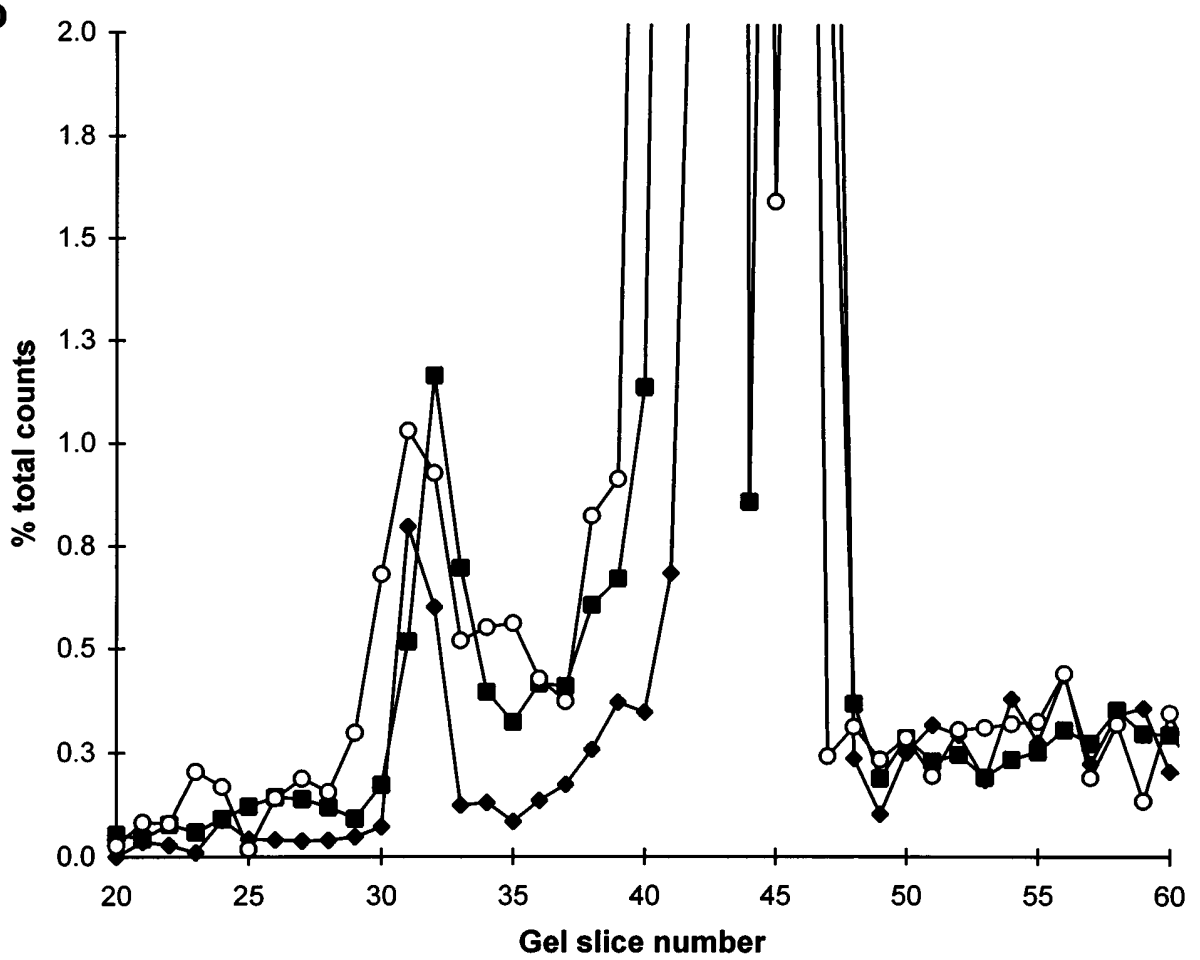

Figure 4 PAGE analysis of EDC cross-linked reactions containing bGH spiked with ${ }^{125}$ I-bGH. Each lane was cut into 2-mm sections and counted on a gamma counter. The MWs of the 'peaks' of ${ }^{125} \mathrm{I}$-bGH containing complexes were assessed by comparison with MW standards run on the same gel. (a) PAGE analysis of

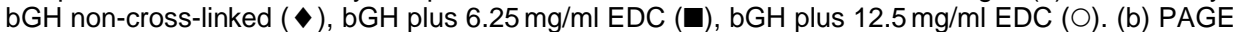
analysis of hGH alone non-cross-linked $(\bullet)$, hGH plus $25 \mathrm{mg} / \mathrm{ml}$ EDC $(\mathbf{\square})$, hGH plus $50 \mathrm{mg} / \mathrm{ml}$ EDC (O). Dimeric bGH was found in gel slices 28-34 and monomeric bGH in gel slices 42-47. 
Table 2 The effect of various concentrations of the cross-linking agent EDC on the biological activity of bGH and the formation of cross-linked bGH dimers. (A) The uptake of ${ }^{35} \mathrm{SO}_{4}{ }^{2-}$ into costal cartilage of Snell dwarf mice (d.p.m./mg cartilage) promoted by bGH crosslinked by various concentrations of EDC $(0-100 \mathrm{mg} / \mathrm{ml})$. (B) The increase in ${ }^{35} \mathrm{SO}_{4}{ }^{2-}$ attributable to the cross-linking process (values for non-cross-linked bGH alone were subtracted from the appropriate EDC cross-linked values). (C) Dimeric bGH present in each reaction as calculated from gel slices from Fig. 4a and b. (D) The percentage of EDC GH dimer attributable to cross-linking with EDC (percentage of bGH dimer in EDC cross-linked reactions minus that in non-cross-linked bGH alone reaction).

\begin{tabular}{|c|c|c|c|c|c|c|c|c|c|}
\hline \multirow{2}{*}{\multicolumn{2}{|c|}{$\begin{array}{l}\text { bGH }(40 \mu \mathrm{g} / \text { day }) \\
\text { EDC }(\mathrm{mg} / \mathrm{ml}) \text { present in } \\
\text { cross-linking reactions }\end{array}$}} & \multirow{3}{*}{$\begin{array}{r}+ \\
- \\
2082\end{array}$} & \multirow{2}{*}{$\begin{array}{l}+ \\
6.25\end{array}$} & \multirow{2}{*}{$\begin{array}{c}+ \\
12.5\end{array}$} & \multirow{2}{*}{$\begin{array}{r}+ \\
25\end{array}$} & \multirow{2}{*}{$\begin{array}{r}+ \\
50\end{array}$} & \multirow{2}{*}{$\begin{array}{c}+ \\
100\end{array}$} & \multirow{2}{*}{-} & \multirow{2}{*}{$\begin{array}{l}- \\
-\end{array}$} \\
\hline & & & & & & & & & \\
\hline$\overline{(A)}$ & $\begin{array}{l}{ }^{35} \mathrm{SO}_{4}{ }^{2-} \text { uptake (dpm) } \\
\text { (plotted values Fig. 4) }\end{array}$ & & 2523 & 2878 & 3611 & 3686 & 3027 & 1179 & 1059 \\
\hline (B) & $\begin{array}{l}\text { Increased }{ }^{35} \mathrm{SO}_{4}{ }^{2-} \\
\text { uptake due to cross- } \\
\text { linking }\end{array}$ & - & 440 & 796 & 1528 & 1604 & 945 & - & - \\
\hline & $\%$ dimer (total) & 1.470 & 1.826 & 2.079 & 2.378 & 2.639 & nd & - & - \\
\hline & $\%$ EDC dimer & 0 & 0.356 & 0.609 & 0.908 & 1.170 & nd & - & - \\
\hline
\end{tabular}

nd, not determined.

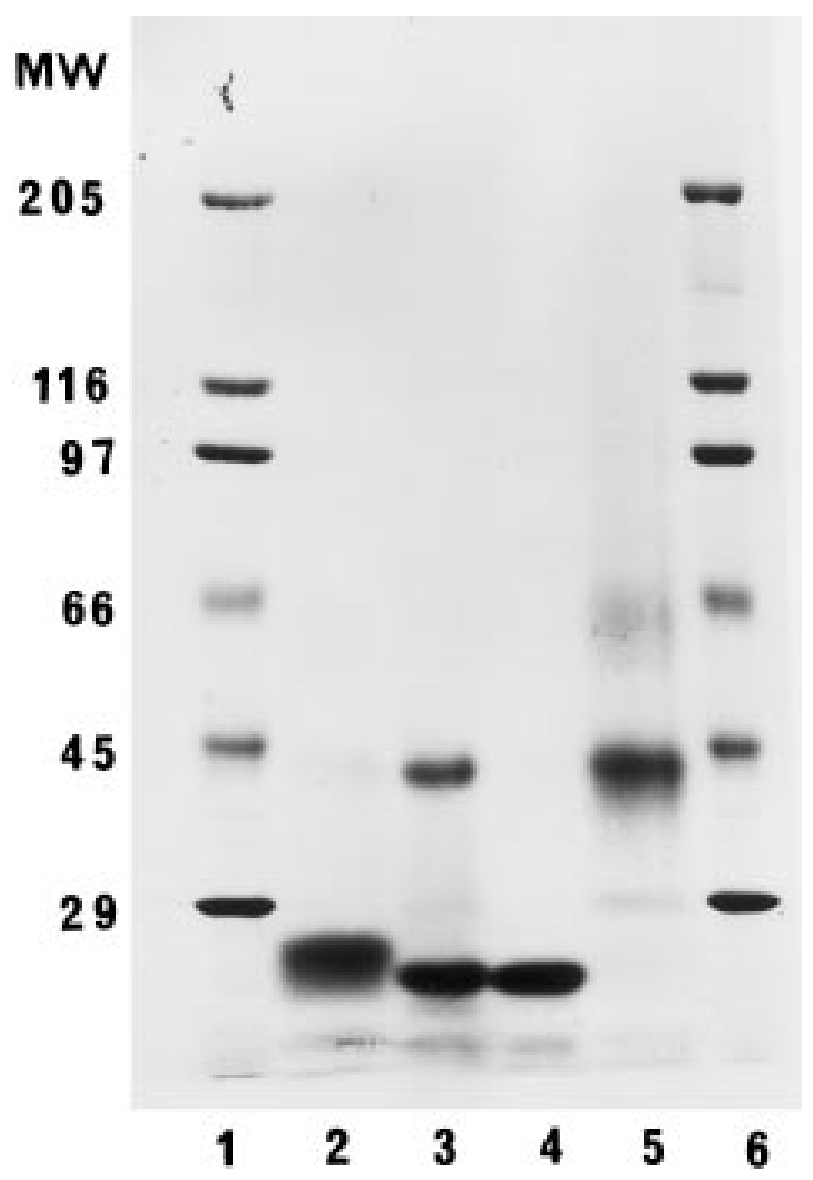

Figure 5 SDS-PAGE analysis of a purified preparation of EDC cross-linked hGH dimers. Lanes 1 and 6 are MW standards. Lane 2 represents the monomeric hGH peak after the second column chromatography run on Sephadex G-50. Our in-house standard preparations of naturally occurring dimeric and monomeric $\mathrm{hGH}$ were run in lanes 3 and 4 respectively. Lane 5 represents the purified preparation of EDC cross-linked dimeric $\mathrm{hGH}$. the nature of these dimers (naturally occurring and EDC cross-linked) are fundamentally different. In essence EDC is a heterobifunctional cross-linking reagent that reacts with available $-\mathrm{COOH}$ groups (found on the terminal residues and aspartic acid and glutamic acid) to form an unstable active $O$-acylisourea intermediate; this intermediate subsequently reacts with free $-\mathrm{NH}_{2}$ groups on amino acids (e.g. lysine) to form an amide bond with the release of a soluble urea derivative as a by-product (32-34). These by-products are unlikely to have a role in the enhancement as the reaction mixtures were thoroughly dialysed and thus removed prior to administration into dwarf mice.

As the cross-linking process is random the structure of the EDC cross-linked dimers and the precise location of the residues involved remains to be determined. Nevertheless, it is likely that they form between residues on the surface of the protein and are postulated not to cause significant disruption of hormone structure or block receptor recognition sites. As the location of covalent linkage is non-specific a number of different molecular species are formed in response to the crosslinking agent (35). These may include a number of different forms of $\mathrm{GH}$ dimer plus monomeric GH with intramolecular bonds and insoluble protein aggregates. However, given the similar biological response of purified EDC-exposed monomer and our monomer preparation it is unlikely that modification of this species contributes to the enhancement. In addition, the data from Fig. 6 demonstrate that purified crosslinked GH dimers have enhanced bioactivity compared with EDC-exposed monomeric hGH.

From Tables 1 and 2 the maximum cross-linking attributable to EDC has been calculated to be only 5\% for hGH and $1 \%$ for bGH. This low level of cross-linking suggests that out of the monomer pool only a small proportion of $\mathrm{GH}$ is present that either has a propensity to dimerise or is in close enough proximity to be crosslinked by EDC even at a high protein concentration. 
Figure 6 The effect of purified EDC crosslinked dimeric $\mathrm{hGH}$ and purified EDC-exposed monomeric hGH on ${ }^{35} \mathrm{SO}_{4}{ }^{2-}$ uptake into costal cartilage in hypopituitary Snell dwarf mice in vivo. Control mice were injected with PBS (hormone diluent). Values are means \pm S.E.M.; $n=6$ per group. All mice received one injection/day for two days. Equivalent doses of monomeric and dimeric $\mathrm{hGH}$ were compared: ${ }^{* * *} P<0.001$

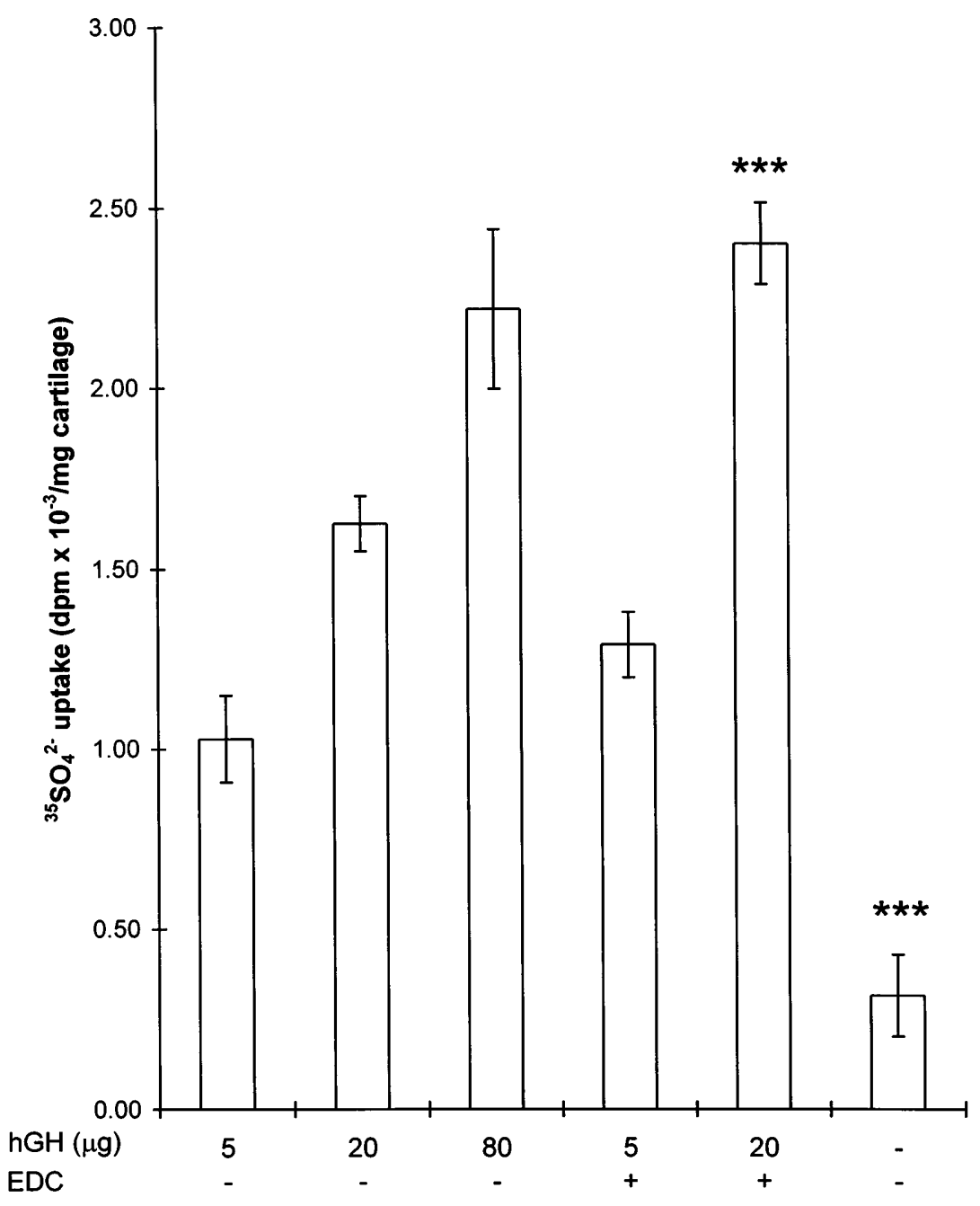

Alternatively, naturally occurring dimers, as identified in the GH preparations in Fig. 2 and Fig. 4, may be replaced by EDC cross-linked dimers. Thus the cross-link would be proposed to stabilise the conformation found in native dimers fundamentally altering its structure and altering its bioactivity.

Enhancement of $\mathrm{GH}$ action has previously been reported when laboratory animals (dwarf mice and dwarf rats) are treated with the hormone complexed to anti-GH monoclonal or polyclonal antibodies (36-41), the $\mathrm{GH}$ binding protein (42) and when covalently linked to polyethylene glycol (43). A number of mechanisms have been suggested to account for this enhancement but as yet the precise mechanism(s) underlying the phenomenon remains unclear. One common mechanism proposed by a number of these workers is that of prolongation of the half-life of the hormone within the circulation $(40,42,43)$. It is suggested that the increased size of the hormone complex (whether the hormone is attached to an antibody, binding protein or covalently linked to another molecule) prevents or delays hormone clearance from the circulation via glomerular filtration and receptor-mediated internalisation and protects from enzymatic degradation. Thus the result would be a circulating pool of bioactive hormone with prolonged half-life and thus prolonged bioactivity. Although there is no direct evidence, it is possible that a similar mechanism may be operating to account for the enhancement of GH activity by EDC cross-linked hGH dimers. Indeed, this mechanism is supported by the finding in the rat that native hGH dimers have an extended serum half-life when compared with monomeric hGH (44). However, although this mechanism may account for the enhanced bioactivity of purified EDC cross-linked dimers it is unlikely that such a mechanism could fully explain the enhanced biological activity of the 'unpurified' EDC-induced dimeric GHs (containing both monomer and dimer).

An alternative mechanism suggests that the binding of $\mathrm{GH}$, whether complexed to an antibody, binding protein or covalently linked to itself, may slow or disrupt the rate of receptor-mediated internalisation of hormone receptor 
complexes $(45,46)$. This delayed receptor internalisation may explain why purified EDC cross-linked dimeric $\mathrm{GH}$ (Fig. 6) was less biologically active than expected. In Fig. 1, GH cross-linked to itself by EDC $(50 \mathrm{mg} / \mathrm{ml})$ gave rise to a $136 \%$ increase in biological activity yet only a small proportion was dimer. In Fig. 6, $20 \mu \mathrm{g}$ purified dimer only gave rise to a $48 \%$ increase in biological activity over that observed for $20 \mu \mathrm{g}$ monomeric $\mathrm{GH}$. Thus it seems on first inspection that the presence of monomeric GH somehow amplifies the response to EDC cross-linked dimeric GH. A plausible explanation would be that delayed receptor internalisation occurs which may also mean delayed receptor recycling and delayed receptor synthesis (47-49); thus the presence of monomeric GH, which is internalised, may facilitate a healthy turnover of, and possibly synthesis of, GH receptors. Much further work on the mechanistic details is necessary.

In this paper we have clearly demonstrated that EDC cross-linked GH dimers have markedly enhanced biological activity in vivo compared with monomeric $\mathrm{GH}$. As yet the mechanism underlying this phenomena is unknown but it appears to operate predominantly via prolongation of the half-life of the hormone and delayed receptor internalisation. With the classification of $\mathrm{GH}$ as a member of the haematopoietin superfamily (7) it is possible that these techniques could be used to enhance the biological activity of other structurally related $4 \alpha$-helix bundle proteins, including a number of cytokines.

\section{References}

1 Nicoll CS, Mayer GL \& Russell SM. Structural features of prolactins and growth hormones that can be related to their biological functions. Endocrine Reviews 19867 169-203.

2 Abdel-Meguid SS, Shieh H-Y, Smith WW, Dayringer HE, Violand BN \& Bentle LA. Three-dimensional structure of a genetically engineered variant of porcine growth hormone. Proceedings of the National Academy of Sciences of the USA 198784 6434-6437.

3 De Vos AM, Ultsch M \& Kossiakoff AA. Human growth hormone and extracellular domain of its receptor: crystal structure of the complex. Science 1992255 306-312.

4 Boulay J-L \& Paul WE Hematopoietin sub-family classification based on size, gene organisation and sequence homology. Current Biology 19933 573-581.

5 Wells JA \& De Vos AM. Structure and function of human growth hormone. Annual Review of Biophysics and Biomolecular Structure 199322 329-351.

6 Horseman ND \& Yu-Lee L-Y. Transcriptional regulation by the helix bundle peptide hormones: growth hormone, prolactin, and haematopoietic cytokines. Endocrine Reviews 199415 627-649.

7 Bazan JF. Haemopoietic receptors and helical cytokines. Immunology Today 199011 350-354.

8 Rui H, Kirke RA \& Farrar WL. Activation of receptor-associated tyrosine kinase JAK2 by prolactin. Journal of Biological Chemistry $19942695364-5368$.

9 Argetsinger LS, Campbell GS, Yang X, Witthuhn BA, Silvennoinen $\mathrm{O}$, Ihle JN \& Carter-Su C. Identification of JAK2 as a growth hormone receptor-associated tyrosine kinase. Cell 1993 74 237-244.

10 Silva CM, Lu H, Weber MJ \& Thorner MO. Differential tyrosine phosphorylation of JAK1, JAK2, and STAT1 by growth hormone and interferon-gamma in IM-9 cells. Journal of Biological Chemistry $199426927532-27539$.
11 Smit LS, Meyer DJ, Billestrup N, Norstedt G, Schwartz J \& Carter-Su $\mathrm{C}$. The role of the growth hormone $(\mathrm{GH})$ receptor and JAK1 and JAK2 kinase in the activation of STATS 1, 3 and 5 by GH. Molecular Endocrinology 199610 519-533.

12 Meyer DJ, Campbell GS, Cochran BH, Argetsinger LS, Larner AC, Finbloom DS, Carter-Su C \& Schwartz J. Growth hormone induces a DNA binding factor related to the interferon-stimulated 91-kDa transcription factor. Journal of Biological Chemistry 1994269 4701-4704.

13 Campbell GS, Meyer DJ, Raz R, Levy DE, Schwartz J \& Carter-Su C. Activation of acute phase response factor (APRF)/STAT3 transcription factor by growth hormone. Journal of Biological Chemistry 1995270 3974-3979.

14 Wood TJJ, Silva D, Lobie PE, Pircher T \& Gouilleux F. Mediation of growth hormone-dependent transcriptional activation of mammary gland factor STAT 5. Journal of Biological Chemistry 1995 $2709448-9453$.

15 Lewis UJ, Bonewald LF \& Lewis LJ. The 20000 dalton variant of human growth hormone: location of the amino acid deletions. Biochemical and Biophysical Research Communications 198092 511-516.

16 Frohman LA, Burer L \& Strachura ME. Characterisation of growth hormone of different molecular weights in rat, dog and human pituitaries. Endocrinology 197291 262-267.

17 Benveniste R, Stachura ME, Szabo M \& Frohman LA. Big growth hormone $(\mathrm{GH})$ : conversion to small $\mathrm{GH}$ without peptide bond cleavage. Journal of Clinical Endocrinology and Metabolism 197541 422-425.

18 Lewis UJ, Peterson SM, Bonewald LF, Seavet BK \& Vanerlaan WP. An interchain disulphide dimer of human growth hormone. Journal of Biological Chemistry 1977252 3697-3702.

19 Tou JS, Violand BN, Schlittler MR \& Jennings MG. Structural characterisation of the two refold dimers of recombinant bovine somatotropin (bST). Journal of Protein Chemistry 199312 237245.

20 Charrier J \& Martal J. Growth hormones. 1. Polymorphism. Reproduction, Nutrition and Development 198828 857-887.

21 Bauman G. Growth hormone heterogeneity: genes, isohormones, variants and binding proteins. Endocrine Reviews 199112 424449.

22 Brostedt P, Luthman M, Wide L, Werner S \& Roos P. Characterisation of dimeric forms of human pituitary growth hormone by bioassay, radioreceptor assay and radioimmunoassay. Acta Endocrinologica 1990122 241-248.

23 Holder AT, Morrell DJ, Lovell RD \& Aston R. Growth hormone activity is enhanced when covalently linked to large protein. Journal of Endocrinology 1989123 (Suppl) 126.

24 Fraker PJ \& Speck JC. Protein and cell membrane iodinations with a sparingly soluble chloroamide, 1,3,4,6-tetrachloro- $2 \alpha, 6 \alpha$ diphenylglycoluril. Biochemical and Biophysical Research Communications $197880849-857$.

25 Laemmli UK. Cleavage of structural proteins during the assembly of the head of bacteriophage T4. Nature $1970227680-685$.

$26 \mathrm{Li} \mathrm{S}$, Crenshaw EB, Rawson EJ, Simons DM, Swanson LW \& Rosenfeld MG. Dwarf locus mutants lacking three pituitary cell types result from mutations in the POV-domain gene pit-1. Nature $1990347528-533$.

27 Roti E, Cristianson D, Harris ARC, Braverman AG \& Vagenakis AG. Short loop feedback regulation of hypothalamic and brain thyrotropin-releasing hormone content in rat and dwarf mouse. Endocrinology 1978103 1662-1667.

28 Slabough MB, Lieberman ME, Rutledge JJ \& Gorski J. Growth hormone and prolactin synthesis in normal and homozygous Snell and Ames dwarf mice. Endocrinology 1981109 10401046.

29 van Buul Offers S. Hormonal and other inherited growth disturbances in mice with special reference to the Snell dwarf mouse. Acta Endocrinologica 1983103 (Suppl 258) 1-47.

30 van Buul-Offers S, Bloemen RJ, Reifen-Gresnigt MG, van Leiden HA, Hoogerbragge CM \& Van der Brande JL. Insulin-like growth 
factors-I and -II and their binding protein during post nata development of Snell dwarf mice before and during growth hormone and thyroxine therapy. Journal of Endocrinology 1994 143 191-198.

31 Holder AT, Wallis M, Biggs P \& Preece MA. Effects of growth hormone, prolactin and thyroxine on body weight, somatomedinlike activity and in vivo sulphation of cartilage in hypopituitary dwarf mice. Journal of Endocrinology 198085 35-47.

32 Hoare DG \& Koshland DE. A procedure for selective modification of carboxyl groups in proteins. Journal of the American Chemical Society 196688 2087-2093.

33 Brinkley M. A brief survey of methods for preparing protein conjugates with dyes, haptens, and cross-linking reagents. Bioconjugate Chemistry $199232-13$

34 Mattson G, Conklin E, Desai S, Nielander G, Savage MG \& Morgensen S. A practical approach to cross-linking. Molecular Biology Reports 199317 127-183.

35 Gupta MN. Cross-linking techniques: applications to enzyme and protein stabilisation and bioconjugate preparation. American Chemical Society Symposium 516 307-324.

36 Holder AT, Aston R, Preece MA \& Ivanyi J. Monoclonal antibodymediated enhancement of growth hormone activity in vivo. Journal of Endocrinology 1985107 R9-R12.

37 Aston R, Holder AT, Preece MA \& Ivanyi J. Potentiation of the somatogenic and lactogenic activity of human growth hormone with monoclonal antibodies. Journal of Endocrinology 1986110 381-388.

38 Bomford R \& Aston R. Enhancement of bovine growth hormone activity by antibodies against growth hormone peptides. Journal of Endocrinology 1990125 31-38.

39 Wang BS, Szewczyk E, Shieh H-M \& Hart IC. Potentiation of the growth-promoting activity of porcine growth hormone (pGH) with an antibody generated in rabbits to the peptide sequence pGH110-118. Journal of Endocrinology $1990127481-485$.

40 Wang BS, Lumanglas AL, Szewczyk E, McWilliams W, Loullis CC \& Hart IC. A proposed mechanism of action of a growth hormonespecific monoclonal antibody in the enhancement of hormona activity. Molecular Immunology 199229 313-317.
41 Beattie J \& Holder AT. Location of an epitope defined by an enhancing monoclonal antibody to growth hormone: some structural details and biological implications. Molecular Endocrinology 19948 1103-1110.

42 Clark RG, Mortensen DL, Carlsson LMS, Spencer SA, McKay P, Mulkerrrin M, Moore J \& Cunningham BC. Recombinant human growth hormone (GH)-binding protein enhances the growthpromoting activity of human GH in the rat. Endocrinology 1996 $1374308-4315$.

43 Clark R, Olson K, Fuh G, Marian M, Mortensen D, Teshima G, Chang S, Chu H, Mukku V, Canova-Davis E, Somers T, Cronin M, Winkler M \& Wells JA. Long-acting growth hormones produced by conjugation with polyethylene glycol. Journal of Biological Chemistry 1996271 21969-21977.

44 Bauman G, Stolar MW \& Buchanan TA. The metabolic clearance, distribution, and degradation of dimeric and monomeric growth hormone $(\mathrm{GH})$ : implications for the pattern of circulating $\mathrm{GH}$ forms. Endocrinology $19861191497-1501$.

45 Holder AT. GH antibodies and somatic growth. In Regulation of Growth Hormone and Somatic Growth, pp 363-398. Ed LF De la Cruz. Amsterdam: Elsevier, 1992.

46 Holder AT \& Carter C. Immunomodulation of the growth hormone-IGF-I axis. Livestock Production Science 199542 229237.

47 Roupas P \& Herington AC. Receptor-mediated endocytosis and degradative processing of growth hormone by rat adipocytes in primary culture. Endocrinology 1987120 2158-2165.

48 Roupas P \& Herington AC. Processing of growth hormone by rat adipocytes in primary culture: differentiation between release of intact hormone and degradative processing. Endocrinology 1987 121 1521-1530.

49 Bick T, Youdim MBH \& Hochberg Z. The dynamics of somatogenic and lactogenic growth hormone binding: internalisation to Golgi fractions in the male rat. Endocrinology $19891251718-1722$.

Received 13 August 1997

Accepted 17 November 1997 